\title{
ANALYSIS OF DEFORMATION PATTERNS THROUGH ADVANCED DINSAR TECHNIQUES IN ISTANBUL MEGACITY
}

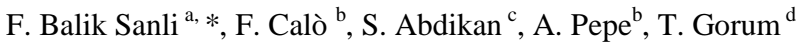 \\ ${ }^{a}$ Yildiz Technical University, Civil Engineering Faculty, Department of Geomatic Engineering, 34220 Esenler-Istanbul, \\ Turkey - fbalik@yildiz.edu.tr, \\ ${ }^{\mathrm{b}}$ National Research Council (CNR) of Italy - Istituto per il Rilevamento Elettromagnetico dell'Ambiente (IREA), \\ Diocleziano 328, 80124 Napoli, Italy - calo.f@irea.cnr.it, pepe.a@irea.cnr.it \\ ${ }^{c}$ BeeSense, Consultancy and Engineering on Geo-information Technologies, 2628 VG, Delft, Netherlands - \\ s.abdikan@beesense.nl \\ ${ }^{\mathrm{d}}$ Natural Sciences Research Center, Yildiz Technical University, Esenler, 34220 Istanbul, Turkey - tgorum@yildiz.edu.tr
}

Commission VII, WG VII/2

KEY WORDS: Differential SAR Interferometry, Small BAseline Subset, TerraSAR-X, Deformation, Monitoring

\begin{abstract}
:
As result of the Turkey's economic growth and heavy migration processes from rural areas, Istanbul has experienced a high urbanization rate, with severe impacts on the environment in terms of natural resources pressure, land-cover changes and uncontrolled sprawl. As a consequence, the city became extremely vulnerable to natural and man-made hazards, inducing ground deformation phenomena that threaten buildings and infrastructures and often cause significant socio-economic losses. Therefore, the detection and monitoring of such deformation patterns is of primary importance for hazard and risk assessment as well as for the design and implementation of effective mitigation strategies. Aim of this work is to analyze the spatial distribution and temporal evolution of deformations affecting the Istanbul metropolitan area, by exploiting advanced Differential SAR Interferometry (DInSAR) techniques. In particular, we apply the Small BAseline Subset (SBAS) approach to a dataset of 43 TerraSAR-X images acquired, between November 2010 and June 2012, along descending orbits with an 11-day revisit time and a $3 \mathrm{~m}$ x $3 \mathrm{~m}$ spatial resolution. The SBAS processing allowed us to remotely detect and monitor subsidence patterns over all the urban area as well as to provide detailed information at the scale of the single building. Such SBAS measurements, effectively integrated with ground-based monitoring data and thematic maps, allows to explore the relationship between the detected deformation phenomena and urbanization, contributing to improve the urban planning and management.
\end{abstract}

\section{INTRODUCTION}

Istanbul is a megacity which is suffered from many natural hazards and lately was affected seriously by the very wellknown Gölcük earthquake occurred in 1999 (Akarvardar et al. 2009; Walter et al. 2010).

Previous studies using InSAR techniques with lower spatial and temporal resolution such as C-band ERS and ENVISAT were presented by many groups (Akarvardar et al. 2009; Walter et al. 2010). For the time period between 1992 and 2010 a mean velocity of $1 \mathrm{~cm} /$ year was monitored (Walter et al. 2010). The region was also suffered from many other natural hazards such as landslides and flooding (Akar et al. 2008, Akarvardar et al. 2009, Einfalt and Keskin 2010).

High resolution SAR imagery has opened a new era for new opportunities for deformation monitoring. Higher spatial and temporal resolution provides higher sensitivity in the results. Advantages of X-band over C-band were successfully indicated in many studies. Ciampalini et al (2014) pointed out high PS density using X-band TerraSAR-X and COSMO-SkyMed over ERS, ENVISAT and RADATSAT-2 data while analysing building deformation in landslide area. Calo et al (2014) investigated landslide area and analysed X-band COSMO-
SkyMed and C-band ERS-ENVISAT measurements. Results showed that X-band measurements improved spatial coverage of deformation. Wegmuller et al. (2010) also concluded that using high spatial resolution TerraSAR-X data gave significantly higher PS density than using ERS or ENVISAT images.

DInSAR analysis of our study area is based on the application of the advanced Small BAseline Subsets (SBAS) approach developed at IREA-CNR, Italy (Berardino et al., 2002). Two key aspects of the SBAS approach make it a powerful tool for temporal and spatial geohazard analyses, namely its capability to provide long-term displacement measurements as well as to carry out a multi-scale investigation of surface deformation.

In this study, urbanized areas which are under risk due to ground deformation are under investigation. In particular, aim of this work is to detect areas affected by deformation over the entire Istanbul city and monitor such zones benefiting of the short revisit time of TerraSAR-X satellite, in order to prevent and mitigate the associated risk.

\footnotetext{
* Corresponding author: Email: fbalik@yildiz.edu.tr
} 


\section{STUDY AREA}

\subsection{Test Site}

The Istanbul province study area extends for about $5300 \mathrm{~km} 2$ at NW of Turkey. The Black Sea lies on the north of Istanbul, and the Marmara Sea lies on the south. These seas are connected with a strait through Bosporus which divides Istanbul city into two regions on the European and Asian continents. The European site is also separated with Golden Horn which has created a peninsula where the old city is located. The city is the second largest metropolitan region in Europe having more than 15 million populations.
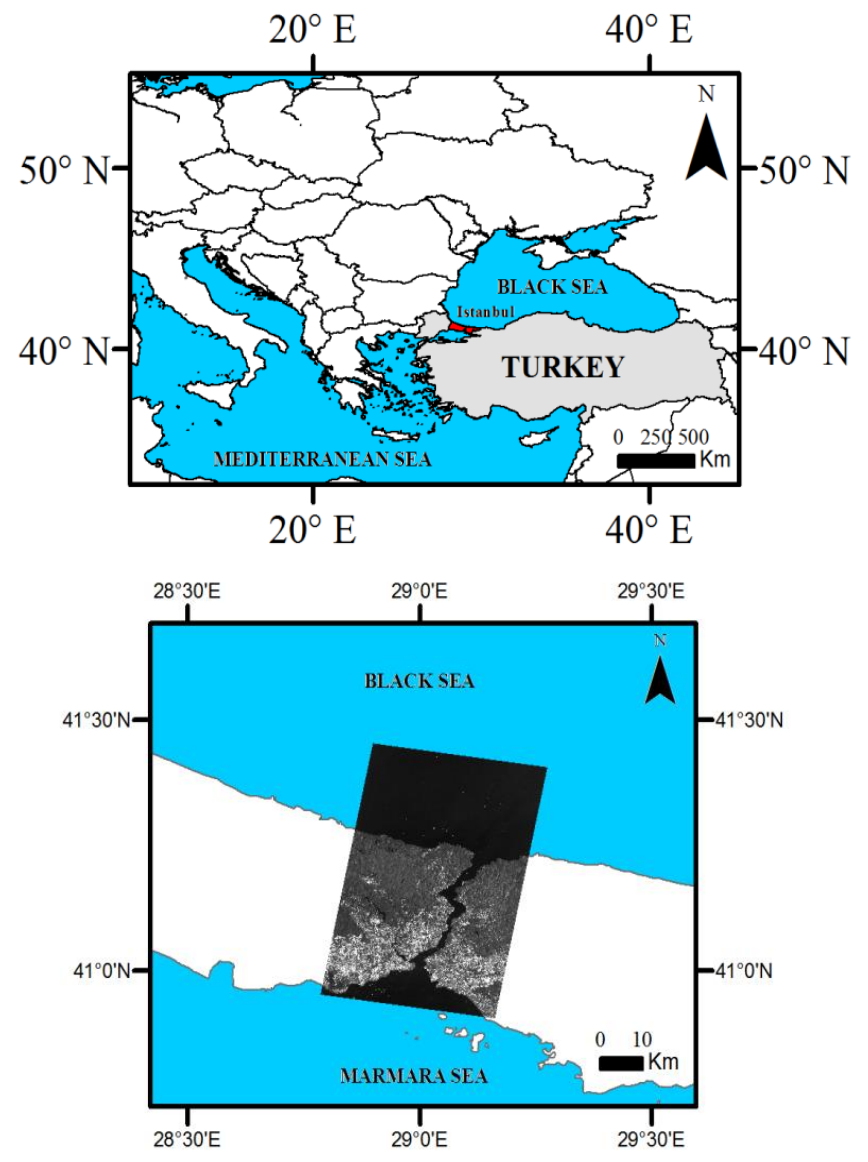

Figure 1. Location of the study area

\section{DINSAR ANALYSIS}

\subsection{Available SAR Data}

We used 43 high resolution TerraSAR-X scenes which are acquired between November 2010 and June 2012 in strip map mode. The dataset was provided by German Aerospace Centre (DLR) under the research project LAN1708. A Digital Elevation Model (DEM) which is produced from 1/5000 scale maps with a $5 \times 5 \mathrm{~m}$ resolution was used to estimate and remove the topographic phase component. The detail of the TerraSAR$\mathrm{X}$ data is given in Table 1 .

\begin{tabular}{|l|c|}
\hline Parameters & Specifications \\
\hline Incidence Angle & $39.8(\min )$ \\
& $42.2(\max )$ \\
Imaging mode & StripMap \\
Beam & Strip_012 \\
Polarization & HH \\
Spatial resolution & 3x3 m \\
\hline
\end{tabular}

Table 1. Specifications of TerraSAR-X data used for study area

\subsection{SBAS Monitoring}

We apply the SBAS-DInSAR technique to the available X-band TerraSAR-X dataset and carried out both regional and local scale analyses (Berardino et al., 2002, Lanari et al., 2004). Here we show the preliminary results of the regional scale SBAS analysis covering a 1.5 year-period. The produced mean deformation velocity map is reported in Figure 2.

In this paper, we focus on the city centre where strait meets the Sea of Marmara, and shoreline of the primary inlet of the strait which is called Golden Horn. The map highlight that the deformation patterns (indicated with red colour) mostly affect the European part of Istanbul. The black circles reported in the figure indicate the deformation areas located in the the northwest and southeast regions of the city characterized by the maximum displacement values. Mean deformation velocity values reach up to $\sim-5 \mathrm{~cm} /$ year in the northwest and $\sim-3.4$ $\mathrm{cm} /$ year in the southeast of the Istanbul urban area (Figure 2). Stable areas are indicated in green colour in Figure 2.

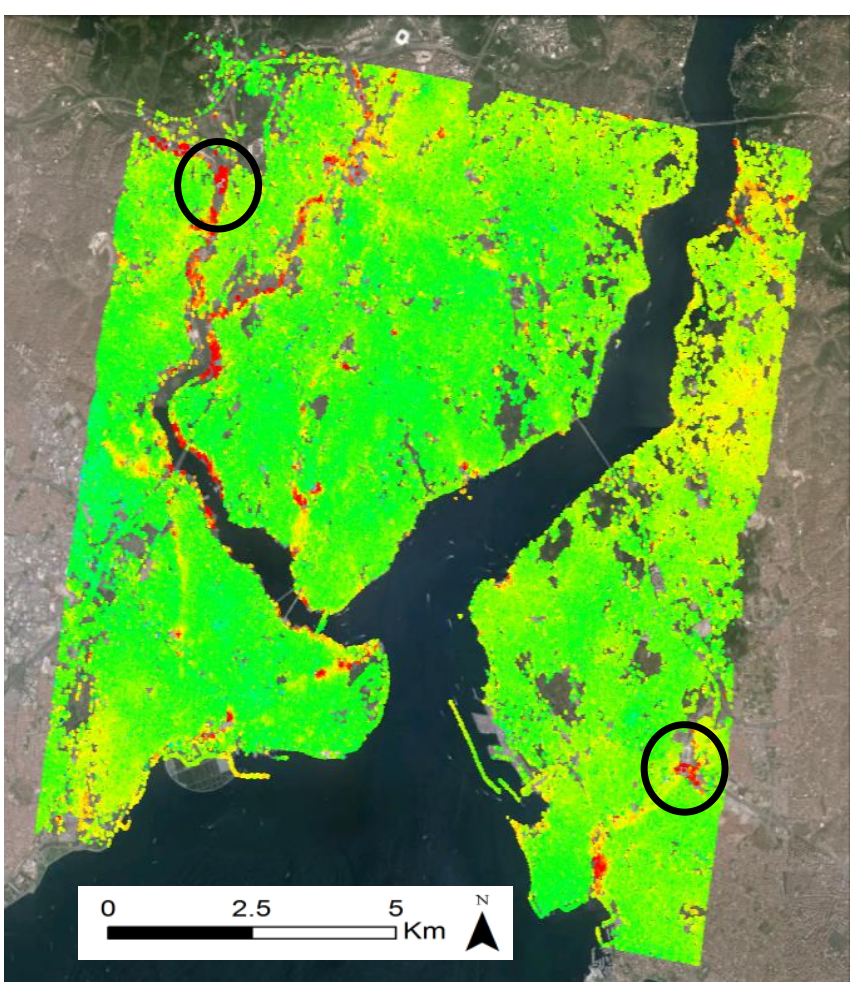

Figure 2. Mean deformation velocity map 


\section{CONCLUSIONS}

We used the advanced SBAS-DInSAR technique to investigate deformation patterns occurring in the megacity Istanbul. The preliminary results, reported in this study, show several areas affected by deformation phenomena within the Istanbul megacity where further analyses need to be carried out and point out as the SBAS approach can be significantly contribute to risk mitigation strategies and sustainable urban planning.

\section{ACKNOWLEDGEMENT}

We thank DLR for providing TerraSAR-X data as a part of scientific project LAN1708.

\section{REFERENCES}

Akar, I., Uysal, C., Maktav, D., 2008. Determination of Natural Disaster by Integration of Remote Sensing and GIS: The Yeniçiftlik Stream Basin Model in Istanbul, Turkey, The International Archives of the Photogrammetry, Remote Sensing and Spatial Information Sciences, Beijing, China, Vol. XXXVII. Part B8, pp. 249-254.

Akarvardar, S., Feigl, K. L. and Ergintav, S., 2009. Ground deformation in an area later damaged by an earthquake: Monitoring the Avcilar district of Istanbul, Turkey, by satellite radar interferometry 1992-1999. Geophys. J. Int., 17 8(2), pp. 976-988.

Berardino, P., Fornaro, G., Lanari, R. and Sansosti, E., 2002. A new Algorithm for Surface Deformation Monitoring based on Small Baseline Differential SAR Interferograms. IEEE Trans. on Geoscience and Remote Sensing, 40 (11), pp. 2375-2383.

Calò, F., Ardizzone, F., Castaldo, R., Piernicola Lollino P., Tizzani, P., Guzzetti, F., Lanari, R., Angeli, M.G., Pontoni, F., Manunt M., 2014. Enhanced landslide investigations through advanced DInSAR techniques: The Ivancich case study, Assisi, Italy, Remote Sensing of Environment, 142, pp. 69-82.

Ciampalini, A., Bardi, F., Bianchini, S., Frodella, W., Del Ventisette, C., Moretti, S., Casagli, N., 2014. International Journal of Applied Earth Observation and Geoinformation, 33, 166-180.

Einfalt, T. and Keskin F., 2010. Analysis of the Istanbul Flood 2009. BALWOIS Conference 2010 - Ohrid, Republic of Macedonia - 25, 29 May 2010.

Lanari, L., Mora, O., Manunta, M., Mallorquí, J.J., Berardino, P. and Sansosti, E., 2004. A Small Baseline Approach for Investigating Deformations on Full Resolution Differential SAR Interferograms, IEEE Transactions on Geoscience and Remote Sensing, 42, pp. 1377-1386.

Wegmuller, U., Walter, D., Spreckels., V., Werner, L.C., 2010. Nonuniform Ground Motion Monitoring With TerraSAR-X Persistent Scatterer Interferometry, IEEE Transactions on Geoscience and Remote Sensing, 48 (2), pp. 895 - 904. 